\title{
KOMPENSASI, LINGKUNGAN KERJA, DAN PROMOSI JABATAN SEBAGAI PREDIKTOR TERHADAP KEPUASAN KERJA KARYAWAN
}

\author{
${ }^{1}$ Program Studi Manajemen, Universitas Tarumanagara \\ Email: hannesw@fe.untar.ac.id \\ ${ }^{2}$ Program Studi Manajemen, Universitas Tarumanagara \\ Email: herlinab@fe.untar.ac.id \\ ${ }^{3}$ Program Studi Manajemen, Universitas Tarumanagara \\ Email: hendraw@fe.untar.ac.id \\ ${ }^{4}$ Program Studi Manajemen, Universitas Tarumanagara \\ Email: ricabulele5@gmail.com
}

Hannes Widjaya ${ }^{1}$, Herlina Budiono ${ }^{2}$, Hendra Wiyanto ${ }^{3}$, Frederica Dharmawan ${ }^{4}$

\begin{abstract}
This study is to detect the effect of compensation, work environment and promotion on employee job satisfaction, where human resources are assets that must be continuosly considered to obtain human resources who have good performance. Human resources in an organization are important and must be managed properly and correctly. Job satisfaction is important because it can affect employee behavior and loyalty to the company. This research was conducted with quantitative methods and the population taken was all employees of the Outbound American division as many as 83 respondents. The sampling technique used was purposive sampling method, and the data testing technique used was PLS. The results of the analysis and discussion showed that compensation, work environment and job promotion had an effect on employee job satisfaction. The compensation variable has a positive effect on employee job satisfaction, The work environment variable has a positive influence on job satisfaction. And lastly, the variable of the job rpomotion has a positive effect oh job satisfaction but is not significant.
\end{abstract}

Keywords: Compensation; Work Environment; Job Promotion; Job Satisfaction

\section{ABSTRAK}

Penelitian ini adalah untuk meneliti kompensasi, lingkungan kerja dan promosi sebagai predictor terhadap kepuasan kerja karyawan. Sumber daya manusia di dalam suatu organisasi menjadi penting dan harus dikelola dengan baik dan benar. Kepuasan kerja menjadi penting karena dapat mempengaruhi perilaku dan loyalitas karyawan pada perusahaan. Dalam penelitian ini dilakukan menggunakan metode kuantitatif. Penelitian ini menggunakan populasi seluruh karyawan bagian Outbound divisi Amerika yang berjumlah 83 responden. Teknik pengambilan sampel yang dipakai metode purposive sampling, dan teknik pengujian data yang digunakan adalah PLS. Hasil dari analisis dan pembahasan diketahui bahwa kompensasi, lingkungan kerja dan promosi jabatan berpengaruh terhadap kepuasan kerja karyawan. Variabel kompensasi memiliki pengaruh positif terhadap kepuasan kerja karyawan. Variabel lingkungan kerja memiliki pengaruh positif terhadap kepuasan kerja. Dan terakhir variabel promosi jabatan juga berpengaruh positif terhadap kepuasan kerja namun tidak signifikan.

Kata Kunci: Kompensasi; Lingkungan Kerja; Promosi Jabatan; Kepuasan Kerja

\section{PENDAHULUAN}

Manusia merupakan makhluk sosial yang dasarnya memiliki sifat untuk bersosialisasi, bekerja sama dan memerlukan keberadaan manusia lainnya (Soegandhi, 2015). SDM menjadi sesuatu yang unik yang harus terus menerus diperhatikan guna mendapatkan tenaga kerja yang memiliki kinerja yang baik, sehingga dapat mengembangkan organisasi/perusahaan dalam berbagai tuntutan masyarakat dan perkembangan jaman. Menurut Jamaluddin (2017), "dalam upaya mendukung pencapaian tujuan organisasi/perusahaan, diperlukan pula sumber daya manusia yang berkualitas dan profesional". SDM yang profesional dan berkualitas cenderung memiliki kinerja yang lebih baik, sehingga upaya peningkatan kualitas sumber daya manusia sangat penting untuk diperhatikan oleh pimpinan organisasi.

Dalam bekerja manusia harus merasakan kepuasan dalam melakukan pekerjaannya. Ini menunjukkan bahwa adanya kepuasan kerja dapat mengukur kesesuaian antara harapan seseorang yang timbul dan imbalan yang disediakan dari pekerjaan. Andriana et al. (2015) 
menyebutkan, "setiap indvidu memiliki tingkat kepuasan yang berbeda sesuai dengan sistem nilai yang berlaku dalam dirinya. Karyawan akan memberikan yang terbaik apabila keinginan sesuai harapannya, sehingga kepuasan karyawan pun akan terpenuhi dan kinerjanya juga meningkat. Makin tinggi penilaian terhadap kegiatan dirasakan sesuai dengan keinginan individu, maka makin tinggi kepuasannya terhadap kegiatan tersebut, dengan demikian kepuasan merupakan evaluasi yang menggambarkan seseorang atas perasaan sikapnya senang atau tidak senang, puas atau tidak puas dalam bekerja".

Tidak sedikit perusahaan yang mengalami permasalahan pada kepuasan kerja karyawannya. Hal ini dapat dilihat mulai dari insentif yang kurang, kesempatan naik jabatan yang rendah, serta tempat kerja yang dirasa kurang nyaman. PT "GRX" adalah perusahaan travel agent di Indonesia yang telah berdiri sejak tahun 1971. Dengan selama hampir 45 tahun "GRX" mengklaim telah membawa lebih dari 250.000 konsumen untuk berkunjung ke berbagai destinasi/area wisata pada setiap tahunnya. "GRX" juga telah bekerjasama dengan hampir 800 maskapai penerbangan dari seluruh dunia, bekerja sama dengan lebih dari lima puluh ribu penginapan dan jasa pariwisata di seluruh dunia, serta telah menjelajahi samudra dengan 12 kapal pesiar.

Berdasarkan pada observasi awal, karyawan tetap akan memperoleh upah yang terdiri dari antara lain upah pokok, bonus, tunjangan THR, dan asuransi. PT "GRX" telah menerapkan UMR sebagai dasar dalam penentuan gaji. Hal ini merupakan satu dari yang paling berpengaruh terhadap tingkat turnover karyawan pada PT "GRX". Berdasarkan hasil wawancara diketahui bahwa tingkat turnover karyawan pada kantor pusat PT "GRX" di Jakarta tertinggi berada pada bulan Maret 2019, karyawan yang keluar ada 3 orang sementara yang masuk tidak ada. Lalu tingkat perputaran tenaga kerja/turnover karyawan terendah ada pada bulan Juli 2019 dimana karyawan keluar sebanyak 1 orang sedangkan karyawan yang masuk sebanyak 4 orang. Adanya tingkat perputaran tenaga kerja/turnover yang tinggi merupakan tolak ukur yang sering dipergunakan sebagai indikasi terjadinya permasalahan kepuasan kerja karyawan di dalam perusahaan.

Selain masalah perputaran tenaga kerja/turnover yang terjadi pada kantor pusat PT "GRX" di Jakarta permasalahan-permasalahan tentang keluhan karyawan yang tidak puas terhadap kebijakan yang dibuat perusahaan contoh tidak adanya jenjang karir yang jelas perusahaan kepada pegawai yang sudah bekerja cukup lama pada perusahaan.

Salah satu usaha yang harus di lakukan untuk meningkatkan kepuasan kerja karyawan adalah dengan kompensasi, yang mempengaruhi bagaimana dan mengapa orang-orang bekerja pada suatu organisasi dan bukan pada perusahaan yang lainnya (Kosmono, 2018). Banyak perusahaan yang sudah memberikan kompensasi tinggi namun tidak selalu membuat karyawan menjadi puas. Kepuasan kerja seseorang tidak selalu hanya dipengaruhi dari besar atau kecilnya kompensasi, namun begitu kompensasi seringkali menjadi pemicu ketidakpuasan karyawan dalam perusahaan. Dalam penelitiannya, Ihsani (2019) mengatakan bahwa "alasan faktor kompensasi berpengaruh dominan terhadap kepuasan kerja karyawan adalah karena kompensasi yang sesuai dengan beban kerja yang telah diberikan kepada karyawan dapat memberikan rasa nyaman dan hubungan interaksi yang baik antara karyawan dengan atasan, atau dengan sesama karyawan".

Menurut Hasibuan (2014) promosi adalah "apabila seorang karyawan dipindahkan dari satu pekerjaan ke pekerjaan lain yang tanggung jawabnya lebih besar, tingkatannya dalam hierarki jabatan lebih tinggi dan penghasilannya pun juga lebih besar". Promosi juga mempunyai nilai lain yang merupakan bukti pengakuan sebuah perusahaan terhadap prestasi kerja karyawannya selama ini. Karyawan yang merasakan adanya kesempatan promosi yang besar dalam perusahaannya merupakan faktor yang mempengaruhi kepuasan dari pekerjaannya (Robbins, 2017). Lain halnya menurut Isyandi (2016) menyebutkan bahwa promosi jabatan adalah 
"menerima kekuasaan dan tanggung jawab lebih besar dari kekuassaan dan tanggung jawab sebelumnya".

"Lingkungan yang nyaman dalam bekerja seperti rekan kerja yang siap membantu dan berinteraksi satu sama lain saat bekerja bahkan pimpinan perusahaan memperlakukan semua karyawan sama dan adil sehingga dapat menghasilkan peningkatan kinerja karyawan serta kinerja seluruh organisasi (Leblebici, 2012)”.

\section{TINJAUAN PUSTAKA}

Kompensasi merupakan balas jasa yang diterima oleh karyawan dari perusahaan tempatnya bekerja yang berupa imbalan. Dessler (2015) menyatakan bahwa "kompensasi karyawan adalah semua bentuk pembayaran atau hadiah yang diberikan kepada karyawan dari pekerjaan mereka dan mempunya dua kompeten: pembayaran langsung (dalam bentuk upah, gaji, insentif, komisi, dan bonus), dan pembayaran tidak langsung (dalam bentuk tunjangan keuangan seperti asuransi, dan uang liburan yang dibayar oleh perusahaan)". Kompensasi merupakan salah satu bentuk penghargaan suatu organisasi terhadap sumber daya manusia yang terlibat di dalamnya, kompensasi yang sesuai dan tepat dapat memberikan pemenuhan kebutuhan dasar karyawan. Dengan pemberian kompensasi, perusahaan mempunyai harapan atas kompensasi yang dibayarkan tersebut kepada karyawan dapat memotivasi dan meningkatkan prestasi kerja karyawan untuk dapat menguntungkan perusahaan Santoso dan Masman (2016) menyatakan bahwa "kompensasi berkenaan dengan segala bentuk balas jasa finansial dan pelayanan tangible (nyata), serta keuntungan yang diterima karyawan sebagai bagian dari suatu hubungan pekerjaan".

Lingkungan kerja yang baik dan memadai bagi karyawannya dapat meningkatkan kinerja, sedangkan lingkungan kerja yang tidak memadai dapat menurunkan kinerja dan motivasi kerja karyawan. Jika karyawan menyenangi tempat bekerjanya, maka hal ini akan membuat karyawan betah bekerja. Menurut Hanggraeni (2012) "lingkungan kerja adalah serangkaian faktor yang mempengaruhi kinerja dari fungsi-fungsi/aktivitas-aktivitas manajemen sumber daya manusia yang terdiri faktor-faktor internal yang bersumber dari dalam organisasi." Sedangkan menurut Gibson (2015) "lingkungan kerja diartikan sebagai suatu kondisi yang berkaitan dengan ciri-ciri tempat bekerja terhadap perilaku dan sikap pegawai".

Menurut Ardana et al. (2012) "promosi adalah proses pemindahan karyawan dari satu jabatan ke jabatan lain yang lebih tinggi, yang diikuti oleh tugas, tanggung jawab, dan wewenang yang menjadi lebih tinggi pula dari jabatan yang diduduki sebelumnya". Sedangkan menurut Sikula yang dikutip oleh Hasibuan (2014) "promosi adalah suatu perpindahan di dalam suatu organisasi dari suatu posisi ke posisi lainnya yang melibatkan baik peningkatan upah maupun status".

Kepuasan kerja merupakan salah satu elemen yang penting dalam organisasi. Hal ini di karenakan kepuasan kerja dapat mempengaruhi perilaku kerja serta loyalitas karyawan di dalam suatu organisasi. "Kepuasan kerja mencerminkan apa yang dirasakan karyawan terhadap pekerjaannya. Kepuasan kerja merupakan sikap umum seorang karyawan terhadap pekerjaannya, Robbins (2017)". Pekerja yang tidak puas cenderung bersikap menentang dalam hubungannya dengan kepemimpinan. Sulaiman dan Herdiani (2018) "menegaskan bahwa kepuasan kerja berhubungan dengan perasaan atau sikap seseorang mengenai pekerjaan itu sendiri, gaji, kesempatan promosi atau pendidikan, pengawasan, rekan kerja, beban kerja dan lain-lain. Kompensasi merupakan salah satu faktor penting dalam perusahaan yang dapat meningkatkan kepuasan kerja karyawan karena kompensasi merangsang karyawan dalam mengerjakan tugas perusahaan dengan sebaik mungkin sehingga mencapai tujuan perusahaan". Sistem kompensasi yang baik akan membuat karyawan merasa dihargai dan merasa cukup dalam memenuhi kebutuhannya sehingga mereka akan termotivasi dalam bekerja. Menurut Yulk (2012), "manfaat 
kompensasi untuk perusahaan yaitu memperoleh karyawan yang bermutu, menciptakan loyalitas dan kepuasan kerja karyawan, serta menunjukkan kesuksesan perusahaan".

Milkovich (2018) "menyebutkan bahwa faktor kompensasi mempunyai pengaruh dominan terhadap kepuasan kerja karyawan karena kompensasi yang sesuai dengan beban kerja yang diberikan pada karyawan dapat memberikan rasa nyaman dan interaksi yang baik antara karyawan dengan atasan". Menurut Damayanti dan Harini (2018) "menyebutkan bahwa kompensasi terhadap kepuasan kerja menghasilkan variabel kompensasi berpengaruh positif dan signifikan terhadap variabel kepuasan kerja”.

Dengan ketersediaannya lingkungan kerja yang mendukung maka hal ini diharapkan dapat menimbulkan kepuasan kerja karyawan dalam perusahaan. "Kepuasan kerja karyawan dalam perusahaan dikatakan tinggi apabila karyawan mudah mendapatkan informasi yang dibutuhkannya untuk melakukan pekerjaan serta nyaman terhadap kondisi di sekitar lingkungan kerjanya (Nugraha dan Surya, 2016)". "Kepuasan kerja menjadi akan lebih tinggi dan niat untuk meninggalkan perusahaan akan lebih rendah apabila lingkungan kerja melengkapi persyaratan kreativitas pekerjaan (Fadli, 2020)". Lingkungan kerja yang kondusif dan nyaman berakibat langsung terhadap meningkatnya kepuasan kerja seorang karyawan.

"Penelitian terdahulu yang dilakukan Faysia et al, (2016) mengatakan adanya hubungan yang signifikan antara promosi jabatan terhadap kepuasan kerja. Apabila seorang karyawan memperoleh promosi, maka jabatan dan kompensasi yang akan diterima secara otomatis juga akan meningkat, hal ini dapat menimbulkan kepuasan kerja yang lebih dari yang sebelumnya".

Berdasarkan pada uraian sebelumnya, dengan adanya lingkungan kerja yang baik maka akan membuat karyawan merasa betah, aman dan nyaman dalam bekerja sehingga produktivitas kerja dan kinerja karyawan tersebut meningkat semakin baik. Faktor-faktor dalam lingkungan kerja antara lain seperti perlengkapan alat kantor yang memadai, ketersediaan fasilitas perusahaan seperti tempat parkir dan musholla, kebisingan dan kebersihan tempat kerja sangat mempengaruhi kepuasan kerja.

Promosi jabatan yang tepat dan berasaskan keadilan dapat meningkatkan kepuasan seorang karyawan tersebut. Oleh karena itu dapat disimpulkan model penelitian dengan variabel berikut ini:

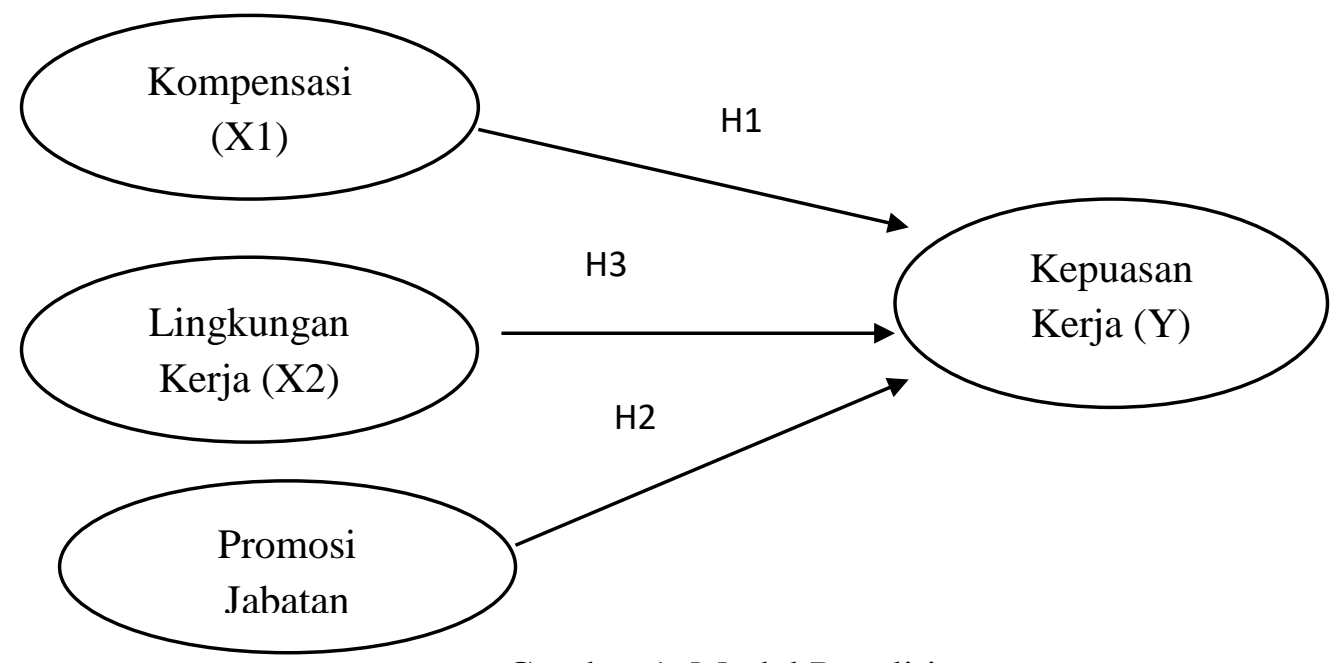

Gambar 1. Model Penelitian

Berdasarkan kerangka pemikiran maka hipotesis penelitian adalah:

H1: kompensasi sebagai prediktor terhadap kepuasan kerja karyawan.

$\mathrm{H} 2$ : promosi jabatan sebagai prediktor terhadap kepuasan kerja karyawan.

H3: lingkungan kerja sebagai prediktor terhadap kepuasan kerja karyawan. 


\section{METODE PENELITIAN}

Penelitian kuantitatif kausal didesain untuk menguji kebenaran empiris antara lebih dari dua variabel yang dirumuskan menjadi hipotesis. Variabel yang mempengaruhi penelitian ini adalah kompensasi, lingkungan kerja dan promosi jabatan. Sedangkan varibel yang dipengaruhi penelitian ini adalah kepuasan kerja karyawan. Penelitian ini menggunakan populasi seluruh karyawan kantor pusat PT "GRX” di Jakarta.

Teknik pengambilan sampel yang digunakan dalam penelitian ini adalah purposive sampling, yaitu "teknik penentuan sampel didasarkan pada kriteria tertentu (Sugiyono, 2012)". Sampel yang diambil adalah seluruh karyawan tetap bagian Outbond Tour (Tour Internasional) divisi Amerika dan telah bekerja minimal 1 tahun pada perusahaan karena karyawan yang telah bekerja selama 1 tahun dianggap sudah memiliki gambaran mengenai perusahaan. Jumlah sampel populasi dalam penelitain ini adalah 83 karyawan

Daftar pertanyaan yang digunakan dalam penelitian ini adalah multikotomis yang berarti daftar pertanyaan yang memiliki lebih dari dua alternatif untuk memberikan tanggapannya terhadap pertanyaan yang diajukan. Penelitian yang digunakan tipe skala ukur yaitu Skala Likert. Penelitian ini menggunakan PLS Structural Equation Modelling (SEM) berbasis kovarian (covariance) menjadi berbasis varian.

\section{HASIL DAN PEMBAHASAN}

Dalam deskripsi subyek penelitian ini, akan diuraikan 83 responden yang dijabarkan mulai dari usia, jenis kelamin, pendidikan terakhir, dan lama bekerja di perusahaan. Hasil dari para responden secara keseluruhan ditampilkan dalam tabel sebagai berikut:

Tabel 1. Rekapan Deskripsi Subyek Penelitian

\begin{tabular}{lcc}
\hline Karakteristik Responden & $\begin{array}{c}\text { Jumlah Responden } \\
\text { Terbanyak }\end{array}$ & Persentase \\
\hline Usia & $19-30$ tahun (75 orang) & $90,4 \%$ \\
\hline Jenis Kelamin & Pria (43 orang) & $51,8 \%$ \\
\hline Pendidikan Terakhir & SMA (42 orang) & $50,6 \%$ \\
\hline Lama Bekerja & $\begin{array}{c}1 \text { sampai 5 tahun (74 } \\
\text { orang) }\end{array}$ & $89,2 \%$ \\
\hline
\end{tabular}

Berikut adalah output SmartPLS untuk menguji validitas. Convergent Validity diuji dengan menggunakan loading factor.. Output SmartPLS untuk loading factor hasil dapat dilihat pada gambar 2 dan Tabel 2 sebagai berikut: 


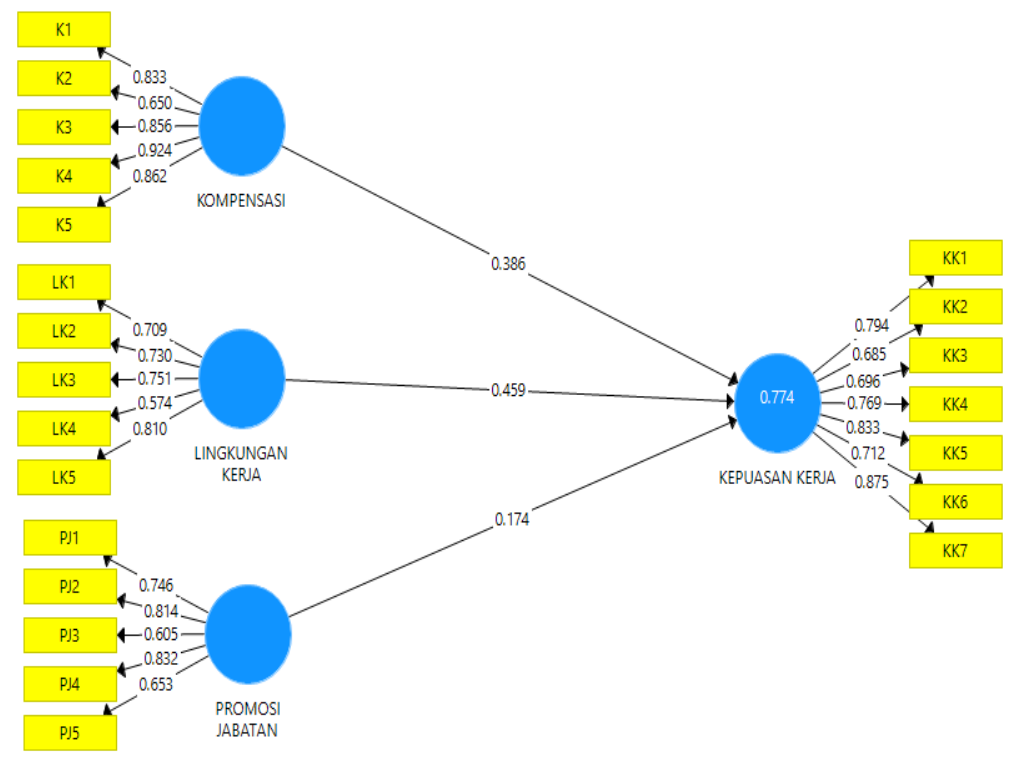

Gambar 2. Output SmartPLS Loading Factor

Gambar 2 menunjukkan loading factor memberikan hasil diatas nilai yang disarankan yaitu lebih dari 0,5. Pada variabel kompensasi, diketahui hasil tertinggi diperoleh pada indikator keempat yaitu kesesuaian gaji yang diterima dengan beban kerja yang dilakukan dengan hasil sebesar 0,924 sementara untuk hasil terendah diperoleh dari indikator kedua yaitu gaji yang saya terima sudah cukup dalam memenuhi kebutuhan pokok dengan hasil sebesar 0,650.

Pada variabel lingkungan kerja, diketahui hasil tertinggi diperoleh dari indikator kelima yaitu saya responden merasakan lingkungan kerja sangat nyaman dan menyenangkan dengan hasil sebesar 0,810 sementara untuk hasil terendah diperoleh padaindikator keempat yaitu perusahaan sering mengadakan acara kumpul sesama karyawan untukmeningkatkan keakraban satu sama lain dengan hasil sebesar 0,574 .

Pada variabel promosi jabatan, diketahui hasil tertinggi diperoleh dari indikator keempat yaitu prestasi kerja karyawan menjadi pertimbangan penting untuk bisa dipromosikan dengan hasil sebesar 0.832 sementara hasil terendah diperoleh dari indikator ketiga yaitu inisiatif dan pengalaman kerja karyawan mempengaruhi kesempatan promosi jabatan di perusahaan ini dengan hasil sebesar 0,605.

Pada variabel kepuasan kerja karyawan, diketahui hasil tertinggi diperoleh dari indikator ketujuh dengan hasil sebesar 0,875 sementara hasil terendah diperoleh dari indikator kedua yaitu atasan saya berlaku adil dan bijaksana terhadap semua karyawan dengan hasil sebesar 0,685. "Sehingga dapat diartikan bahwa indikator yang dipergunakan dalam penelitian ini valid atau telah memenuhi convergent validity (Ghozali, 2014)".

Setelah diuji convergent validity maka selanjutnya akan diuji nilai Average Variant Extracted.

Tabel 2. Average Variant Extracted (AVE) dan Cronbach Alpha

\begin{tabular}{lcc}
\hline & AVE & Cronbach'Alpha \\
\hline Kompensasi (K) & 0,690 & 0,883 \\
\hline Lingkungan Kerja (LK) & 0,517 & 0,764 \\
\hline Promosi Jabatan (PJ) & 0,541 & 0,788 \\
\hline Kepuasan Kerja (KK) & 0,592 & 0,883 \\
\hline
\end{tabular}

Berdasarkan tabel 2 dapat diketahui nilai AVE dari setiap variabel adalah lebih besar dari 0,5 sehingga berarti bahwa semua variabel telah memiliki discriminant validity yang baik. 
Pengujian reliabilitas dapat dilihat pula pada tabel 3 nilai alpha-cronbach untuk tiap variabel adalah lebih besar dari 0,7 sehingga berarti pernyataan dari setiap variabel adalah reliable. Dalam analisis data mengenai kompensasi, lingkungan kerja, dan promosi jabatan nerupakan predikitor terhadap kepuasan kerja karyawan PT "GRX" di Jakarta, maka dapat dilihat dari data kuesioner yang telah diberikan oleh karyawan PT "GRX” Jakarta.

\section{Uji Koefisien Determinasi $\left(\mathbf{R}^{\mathbf{2}}\right)$}

Pengujian model struktural (inner model) dilakukan untuk melihat hubungan antara variabel $R$ square. Berikut adalah nilai $R$ square pada Tabel 3.

Tabel 3. Koefisien Determinasi $\left(\mathbf{R}^{\mathbf{2}}\right)$

\begin{tabular}{ccc}
\hline & R Square & R Square Adjusted \\
\hline Kepuasan Kerja (Y) & 0,775 & 0,766 \\
\hline
\end{tabular}

Berdasarkan hasil Adjusted $R$ Square $\left(\mathrm{R}^{2}\right)$ pada tabel 3 adalah sebesar 0,765 yang berarti proporsi dari kompensasi, lingkungan kerja, dan promosi jabatan adalah $76,6 \%$ dan sisanya sebesar 23,4\% dijelaskan dalam variabel-variabel lainnya. Sedangkan hubungan kepuasan kerja terhadap kompensasi, lingkungan kerja dan promosi jabatan berdasarkan nilai $R$ Square adalah 0,775 yang berarti positif dan signifikan bahwa hubungan kepuasan kerja terhadap kompensasi, lingkungan kerja, dan promosi jabatan.

\section{Uji Hipotesis}

Variabel Independen menunjukkan tingkat signifikan apabila nilai $\mathrm{t}$ value $\geq 1,96$ pada tingkat alpha $5 \%$.

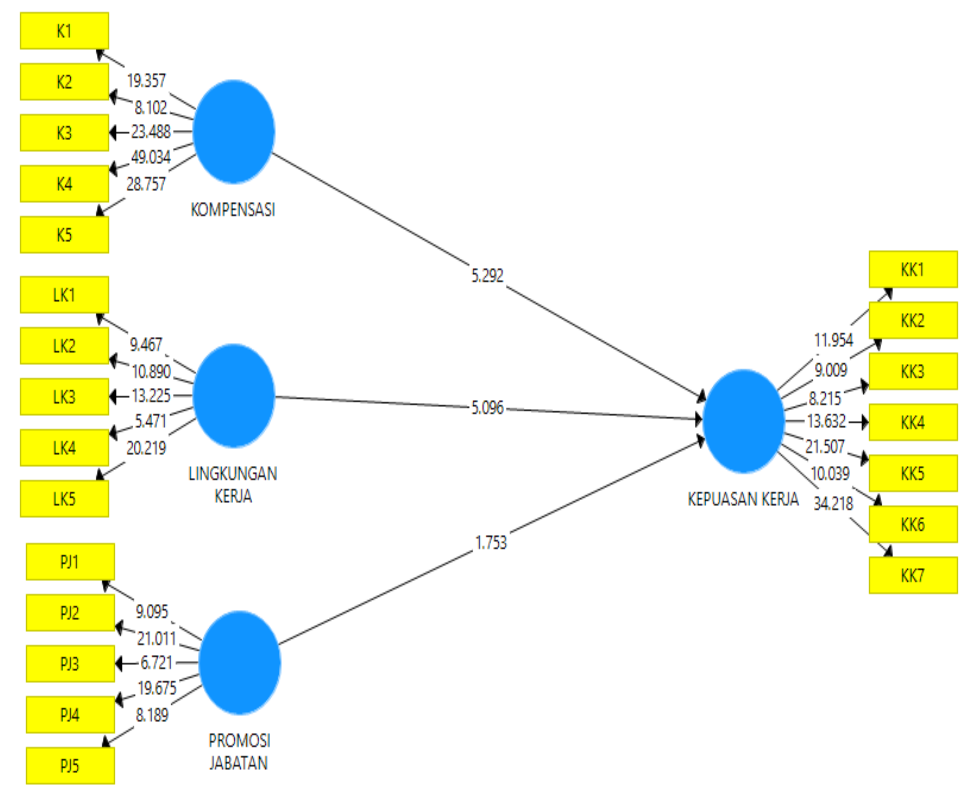

Gambar 3. Output Smart PLS Bootstrapping

Dari hasil uji signifikan untuk pengaruh secara langsung di atas maka dijelaskan hipotesis sebagai berikut: Dari hasil pengujian kompensasi terhadap kepuasan kerja karyawan memiliki koefisien jalur 0,386 dan t-value sebesar 5,292 dimana t-value sebesar 1,96. Maka dari itu dapat disimpulkan kompensasi memiliki pengaruh signifikan terhadap kepuasan kerja karyawan PT "GRX" di Jakarta. 
Hasil pengujian lingkungan kerja terhadap kepuasan kerja karyawan memiliki koefisien jalur 0,459 dan t-value sebesar 5,096 dimana t-value sebesar 1,96. Oleh karena itu dapat disimpulkan bahwa lingkungan kerja memiliki pengaruh signifikan terhadap kepuasan kerja karyawan PT "GRX" di Jakarta.

Hasil pengujian promosi jabatan terhadap kepuasan kerja karyawan memiliki koefisien jalur 0,174 dan t-value sebesar 1,753 dimana t-value sebesar 1,96. Sehingga dapat ditarik kesimpulan bahwa promosi jabatan memiliki pengaruh tetapi tidak signifikan terhadap kepuasan kerja karyawan PT "GRX" di Jakarta.

Uji Goodness of Fit ini digunakan dalam menilai ketepatan model yang diuji, apakah model tersebut baik (fit) atau tidak. Ketepatan pada model ini dibuat dalam bentuk tabel yang dapat dilihat pada tabel 4 .

Tabel 4. Hasil Uji Goodness of Fit

\begin{tabular}{cc}
\hline & Saturated Model \\
\hline NFI & 0,623 \\
\hline
\end{tabular}

Nilai ini berkisar dari 0-1, nilai NFI yang mendekati 1 menunjukkan bahwa model yang diuji memiliki ketepatan yang baik. Dalam menguji nilai dari ketepatan yang baik. Dalam menguji nilai dari ketepatan sebuah model dengan PLS dapat dilihat dari NFI.

\section{KESIMPULAN DAN SARAN}

Pada kompensasi diketahui sebagai prediktor terhadap kepuasan kerja karyawan. PT "GRX" telah memberikan gaji, upah, bonus, dan insentif yang sesuai kepada karyawannya. Perusahaan juga memberikan tanda apresiasi kepada karyawannya atas kinerja yang mereka lakukan dan prestasi kerja mereka yang baik dalam pencapaian tujuan perusahaan. Perusahaan juga selalu memberikan gaji tepat waktu. Hasil penelitian terdahulu yang dilakukan oleh Tresna (2014) pada karyawan PT. Anugrah Merta Sari Sedana Denpasar, hasil analisis menunjukkan bahwa kompensasi, kepemimpinan, dan lingkungan kerja secara parsial sebagai prediktor terhadap kepuasan kerja disana.

Pada variabel lingkungan kerja diketahui merupakan prediktor terhadap kepuasan kerja karyawan. Lingkungan kerja yang dimiliki PT "GRX" di Jakarta sangat menyenangkan bagi karyawannya. Hal ini dapat dilihat dari hasil penelitian yang menyatakan terdapat sebesar 51 responden menjawan setuju dan 28 responden menjawab sangat setuju untuk pernyataan lingkungan kerja nyaman dan menyenangkan. Lengkapnya fasilitas yang tersedia, ruang kerja yang bersih dengan interior yang rapi nan indah, serta rekan kerja yang dapat diajak kerjasama dengan baik menjadikan karyawan PT "GRX" merasa puas dengan lingkungan kerjanya. Penelitian yang sama dilakukan oleh Yakub (2016) dalam artikelnya yang berujudul "Pengaruh Kompensasi, Lingkungan Kerja dan Promosi Jabatan Terhadap Kinerja Kerja Karyawan yang menyatakan bahwa lingkungan kerja memberikan pengaruh positif dan signifikan terhadap kinerja karyawan.

Pada promosi jabatan diketahui memiliki pengaruh positif terhadap kepuasan kerja namun tidak signifikan. Hal ini dikarenakan karyawan PT "GRX" di Jakarta merasa atasan mereka yang tidak berlaku adil dan bijaksana terhadap semua karyawan.. Penelitian ini berbeda dengan penelitian terdahulu yang dilakukan oleh Magdalena dan Rulyanti (2019) yang menyatakan adanya hubungan signifikan antara promosi jabatan terhadap kepuasan kerja.

Dari hasil penelitian yang telah dilakukan, saran yang dapat diberikan yang bagi perusahaan adalah sebagai pihak manajemen PT "GRX" baiknya lebih memerhatikan lagi insentif bagi karyawan yang benar-benar berprestasi atau menembus jauh target, terutama besaran gaji pokok yang dirasa kurang dalam memenuhi kebutuhan pokok berdasarkan hasil dari penelitian kuesioner yang telah dilakukan. Hal ini bertujuan agar karyawan menjadi semakin termotivasi 
dan loyal pada perusahaan serta memberikan kinerjanya yang terbaik dalam pencapaian tujuan perusahaan.

Lingkungan kerja PT "GRX" dikatakan memiliki penilaian yang sudah baik dilihat dari hasil penelitian kuesioner karyawannya. Namun lingkungan kerja dapat terus lebih ditingkatkan lagi dengan semakinlengkap tersedianya fasilitas kantor yang ada, juga perlunya diadakan lebih sering acara kumpul bersama di dalam ataupun di luar kantor guna mempererat hubungan keakraban antar sesama rekan kerja karyawan dengan atasan. Hal ini dimaksudkan agar semakin terciptanya budaya harmonis dalam perusahaan sehingga komunikasi antar karyawan semakin baik dan tingkat kerjasama antar rekan kerja yang semakin meningkat.

Pihak manajemen PT "GRX" kiranya dapat memperhatikan lebih lagi tentang pemberian promosi sesuai dengan tingkat pendidikan karyawan sehingga karyawan dapat merasakan keadilan dan kebijaksanaan atasan dalam memberikan promosi, juga agar kepuasan kerja yang sudah diperoleh tidak akan rendah. Pemberian promosi jabatan bagi pegawai yang berprestasi dalam bekerja adalah penting, karena disamping karyawan lain merasa hal itu adalah adil, juga karyawan berprestasi tersebut akan dapat terus meningkatkan lagi prestasinya dalam bekerja serta menjaga tingkat kepuasan kerjanya dan loyal pada perusahaan.

\section{Ucapan Terima Kasih (Acknowledgement)}

Terima kasih sebesar-besarnya kepada LPPM Untar atas kerjasama mendukung penelitian ini.

\section{REFERENSI}

Andriana, A. N., Rasyidi, M. N., \& Utomo, S. (2015). Pengaruh Kepuasan Kerja, Motivasi Dan Disiplin Terhadap Kinerja Karyawan Outsourcing Pada PT. Sindy Hutama Karya Kabupaten Paser. Jurnal Bisnis dan Pembangunan.

Ardana, Komang, Ni Wayan Mujiati dan I Wayan Mudiartha Utama, (2012). Manajemen Sumber Daya Manusia (Edisi Pertama). Yogyakarta: Graha Ilmu.

Dessler, G., (2015) Human Resources Management Sixteen Edition. Pearson Education INC. United States.

Ghozali, I. (2014). Aplikasi multivariate dengan program SPSS. Semarang: Badan Penerbit Universitas Diponogoro.

Hasibuan. (2014). “Manajemen Sumber Daya Manusia”. Edisi Tevisi. Jakarta: PT Bumi Aksara.

Ihsani, N., \& Wijayanto, A. (2020). The Effect of Organizational Culture, Motivation, And Job Satisfaction on Employee Performance. Dinasti International Journal of Digital Business Management.

Isyandi, B. (2016). Manajemen Sumber Daya Manusia Dalam Perspektif Global. Edisi Kedua, Pekanbaru: Unri Press.

Jamaluddin, J., Salam, R., Yunus, H., \& Akib, H. (2017). Pengaruh Budaya Organisasi terhadap Kinerja Pegawai pada Dinas Pendidikan Provinsi Sulawesi Selatan. Jurnal Administrare.

Koesmono, H. T. (2018). Pengaruh budaya organisasi terhadap motivasi dan kepuasan kerja serta kinerja karyawan pada sub sektor industri pengelohan kayu skala menengah di jawa timur. Jurnal manajemen dan kewirausahaan.

Leblebici, D. (2012). Impact of Workplace Quality on Employee's Productivity: Case Study of a Banking Turkey. Journal of Business, Economics, and Finance. Vol.1.

Made, Bayu, Indra, Nugraha. \& Ida Bagus Ketut Surya (2016). Pengaruh Kompensasi, Lingkungan Kerja dan Promosi Jabatan Terhadap Kepuasan Kerja. E-Jurnal Manajemen. Udayana, Bali.

Magdalena Faysia., Bernhard, Tewal \& Mac, Donald Walangitan (2019). "Pengaruh Motivasi Kerja, Kompensasi Dan Promosi Jabatan Terhadap Kepasan Kerja Karyawan Hal 672-684. E-Jurnal Jurnal BerkalaI Ilmiah Efisiensi: Unversitas Sam Ratulangi, Manado. 
Milkovich, G. T. dan Jerry M. Newman. (2018). Compensation. $8^{\text {th }}$ edition. Singapore: Mc. Graw-Hill Company.

Robbins, Stephen P. (1917). Organizational Behaviour. Sixteenth Ed. New Jersey: Prentice-Hall, Inc.

Santoso, Yussy, \& Masman. Ronnie R., (2016). Executive Compensation Management. Jakart: Elex Media Komputindo.

Silviana, Damayanti, \& Dri, Harini. (2018). "Pengaruh Promosi Jabatan Dan Kompensasi Terhadap Kepuasan Kerja Karyawan Pada PT. Pertiwi Margasakti Jakarta, Hal 22- 32 Jurnal Visionida Vl 4 Nomor 1. Universitas Djuanda, Bogor, Jawa Barat.

Soegandhi, V. M., Sutanto, E. M., \& Setiawan, R. (2015). Pengaruh Kepuasan Kerja dan Loyalitas Kerja terhadap Organizational Citizenship Behavior pada Karyawan PT. Surya Timur Sakti Jatim. Agora.

Sopiah. (2008). Perilaku Organisasi. Yogyakarta: Andi Offset.

Sugiyono. (2003). Metode Penelitian Bisnis. Edisi 1, Bandung: Alfabeta.

Sulaiman, M., \& Herdiani, S. (2018). "Pengaruh Motivasi Dan Kepuasan Kerja Terhadap Disiplin Kerja Dan Dampaknya Terhadap Kinerja Pegawai Dinas Pertanian Dan Ketahanan Pangan Kota Banjar, Hal 12-14. E-Jurnal Manajemen. Unversitas Udayana.

Tresna Suputra Angelo Confessa, I Made. (2014). "Pengaruh Kompensasi, Kepemimpinan Dan Lingkungan Kerja terhadap Kepuasan Kerja Karyawan pada PT. Anugrah Merta Sari Sedana Denpasar". E-Jurnal Manajemen. Unversitas Udayana.

Hanggraeni, Dewi., (2012). Manajemen Sumber Daya Manusia. Jakarta: Lembaga Penerbit FE Universitas Indonesia.

Yakup (2016) "Pengaruh Kompensasi, Lingkungan Kerja dan Promosi Jabatan Terhadap Kinerja Kerja Karyawan. Hal 95-112. Journal of Management V1 2 No.1.

Yulk, Gary. (2015). Kepemimpina Dalam Organisasi. Edisi Ketujuh. Jakarta: Indeks Indonesia. 